OSOBA | WARTOŚCI

Filozofia Chrzé́cijańska • Tom 8, Poznań 2011

Uniwersytet im. Adama Mickiewicza • Wydziat Teologiczny

\author{
KRZYSZTOF STACHEWICZ \\ Uniwersytet im. Adama Mickiewicza \\ Wydział Teologiczny \\ Zakład Filozofii Chrześcijańskiej
}

\title{
Józefa Tischnera myślenie według czy przeciw wartościom?
}

Józef Tischner's Thinking According or Against Values?

Tytułowe pytanie jest zdecydowanie czymś więcej niż retoryczną prowokacją, choć taką może się początkowo wydawać. Wszak już tytuł jednej z najważniejszych książek Józefa Tischnera - często reklamowanej na rynku wydawniczym jako jedna $\mathrm{z}$ najważniejszych polskich książek filozoficznych dwudziestego wieku - zdaje się jednoznacznie udzielać odpowiedzi na pytanie postawione $\mathrm{w}$ tytule tego wystapienia. Tradycja fenomenologiczna, z której wyszedł Tischner - jego pierwszym mistrzem filozoficznym był Ingarden, pod którego kierunkiem przygotował pracę doktorską, poświęconą koncepcji ja transcendentalnego u Husserla, a rozprawę habilitacyjną napisał w duchu twórcy fenomenologii - wyraźnie i naturalnie kierowała go ku aksjologicznemu opisowi rzeczywistości. „Wartość” jawiła się bowiem fenomenologom jako neutralna i czysto deskryptywna kategoria pojęciowa, doskonale kompatybilna z bezpośrednim doświadczeniem ważności, doniosłości, tego, co język niemiecki wyraża słowem Bedeutsamkeit. „Wartość” zdawała się optymalnie oddawać istotę doświadczenia tej doniosłości, wyrażać ją i komunikować innym. Jako kategoria etyczna jawiła się w funkcji swoistego petryfikatora żywych treści doświadczenia aksjomoralnego, gwarantując - w duchu fenomenologicznej zasady zasad - egzystencjalno-doświadczalny punkt wyjścia teorii etycznej i eo ipso jej niezależność od metafizyki oraz innych nauk, tak filozoficznych, jak i społecznych. Doświadczenie etyczne jest intencjonalnym doświadczeniem wartości moralnych lub moralnie doniosłych. Stąd etyka w fenomenologii - u Edmunda Husserla, Maxa Schelera, Nicolaia Hart- 
manna, Dietricha von Hildebranda, Romana Ingardena, Hansa Reinera, Josefa Seiferta i wielu innych - przybierała, niezależnie od znaczacych i istotnych różnic, nieodmiennie charakter materiale Wertethik, a optyka aksjologiczna jawiła się jako najbardziej adekwatna dla uchwycenia i opisu istoty człowieka i natury jego egzystencji, w tym także egzystencji moralnej.

Rozpatrując problemy etyczne młody Tischner, w duchu fenomenologii, odwoływał się dość bezkrytycznie do klasyki materialnej etyki wartości, w sposób szczególny do analiz Maxa Schelera, zawartych w Der Formalismus in der Ethik und materiale Wertethik. Duch materialnej etyki wartości jest wyraźny w jego książce zatytułowanej Etyka wartości i nadziei, w wielu tekstach publikowanych pierwotnie w miesięczniku „Znak” oraz w wykładach uniwersyteckich wydanych niedawno w tomie pt. Etyka a historia ${ }^{2}$. „Kluczem do etyki jest doświadczenie wartości" - pisał . Etykę określał wręcz jako teorię człowieka, będącego „tworzywem” dla wartości ${ }^{4}$. Warto podkreślić, że Tischnerowskie myślenie według wartości to myślenie w żywiole aksjologii wyłącznie fenomenologicznej, całkowicie abstrahującej od innych paradygmatów ogólnej teorii wartości, jak choćby od neokantyzmu badeńskiego. Ten jednoznacznie aksjologiczny obraz myślenia Tischnera ulegał jednak z biegiem lat coraz większej komplikacji teoretycznej aż do wypowiedzi, stawiających pod znakiem zapytania stosowanie strategii aksjologicznej na gruncie etyki i filozofii człowieka. Podkreślanie wagi spotkania z drugim człowiekiem, operowanie kategorią dobra i dramatu powodowały w myśleniu Tischnera rozliczne napięcia, z których tylko częściowo zdawał sobie sprawę. I właśnie to sprawia, że nasze tytułowe pytanie jest nie tylko zasadne, ale trafia w bardzo istotny nerw myślenia filozoficznego Józefa Tischnera. Jednak ten aspekt z zakresu historii polskiej filozofii najnowszej nie wyczerpuje, jak można sądzić, doniosłości poruszanego problemu. Zagadnienie aksjologicznego gruntowania etyki oraz współczesnej wszechobecności frazeologii związanej ze słowem „wartość”, leży na przedłużeniu powyższego pytania, a doniosłości tych zagadnień przecenić się nie da. Ta niebywała popularność słowa „wartość” nie tylko na gruncie filozofii, ale i teologii, nauk społecznych, a także w dyskursie publicznym i języku potocznym, wymaga od filozofa podejrzliwości, krytycyzmu i dystansu, a nie bezrefleksyjnej afirmacji. Przygoda Tischnera z myśleniem według wartości jest interesującym i istotnym przy-

\footnotetext{
${ }^{1}$ Por. np. J. Tischner, Wartości etyczne i ich poznanie, „Znak” 215, 1972, s. 629-646.

${ }^{2}$ Por. tenże, Etyka a historia. Wyktady, opr. D. Kot, Kraków 2008, s. 329-493.

${ }^{3}$ Tenże, Etyka wartości i nadziei, w: D. v. Hildebrand, J.A. Kłoczowski, J. Paściak, J. Tischner, Wobec wartości, Poznań 1982, s. 52.

${ }^{4}$ Por. tamże, s. 55.
} 
czynkiem do tego ogólniejszego problemu i doniosłych z punktu widzenia etyki fundamentalnej dyskusji wokół niego.

\section{MYŚLENIE WEDŁUG WARTOŚCI}

\section{Pisał Martin Heidegger w Liście o humanizmie:}

Myślenie podług wartości jest tu i wszędzie największym bluźnierstwem, jakie można pomyśleć przeciwko byciu. A więc myśleć przeciw wartościom wcale nie znaczy: bić w bęben na cześć bezwartościowości i marności bytu - znaczy ono: wbrew subiektywizacji bytu, która czyni z niego jedynie przedmiot, stawiać przed myślenie prześwit prawdy bycia 5 .

Tłumacz tego tekstu na język polski, Józef Tischner, początkowo zdecydowanie sprzeciwiał się obiekcjom Heideggera przeciw wartościom, nie widząc zupełnie racji, które kazały Heideggerowi użyć mocnego określenia Blasphemie (bluźnierstwo) w odniesieniu do das Denken in Werten, choć - jak postaram się pokazać - stanowisko Heideggera posiało w nim wątpliwości, które miały powoli, choć zdecydowanie owocować, zmieniając jego ogólne nastawienia metafilozoficzne. Raczej nieprzypadkowo, jako wyraźny sprzeciw wobec Heideggera, jeden ze swych znanych i niejako programowych tekstów Tischner tytułuje Myślenie wedtug wartości. Czas powstania tej rozprawy (1978) oraz tłumaczenia Listu o humanizmie Heideggera (1976) jest zbieżny, a zatem przypadkowość jest tu bardzo mało prawdopodobna. Później tytuł tekstu przechodzi na głośny tom Tischnera wydany w „Znaku” w roku 1982. Zresztą perspektywa aksjologiczna nadaje ton także jego wcześniejszej książce pt. Świat ludzkiej nadziei, zawierającej artykuły i szkice filozoficzne z lat 1966-1975, choć autor nie używa tam sformułowania „myślenie według wartości”.

Pryzmat aksjologiczny Tischnerowskiego widzenia rzeczywistości z tego okresu oddają m.in. słowa:

Aby zachować się właściwie w tym naszym małym świecie, musimy umieć „czytać wartości”. Nie witamy się z krzesłami, nie usiłujemy szukać dla siebie miejsca na kolanach ludzi już siedzacych. Bez koniecznej potrzeby nie siadamy tyłem do kate-

\footnotetext{
${ }^{5}$ M. Heidegger, List o humanizmie, thum. J. Tischner, w: M. Heidegger, Znaki drogi, Warszawa 1999, s. 300. W tekście oryginalnym zdania te brzmią następująco: „Das Denken in Werten ist hier und sonst die grösste Blasphemie, die sich dem Sein gegenüber denken lässt. Gegen die Werte denken, heisst daher nich, für die Wertlosigkeit und Nichtigkeit des Seienden die Trommel rühren, sondern bedeutet: gegen die Subjektivierung des Seienden zum blossen Objekt die Lichtung der Wahrheit des Seins vor das Denken bringen".
} 
dry. Nasz obecny świat jest niewątpliwie światem jakichś wartości, a my w nim jesteśmy istotami czytającymi wartości ${ }^{6}$.

Świat bez wartości nie jest już światem człowieka ${ }^{7}$, stąd aksjologia jawi się jako klucz hermeneutyczny do zrozumienia rzeczywistości człowieka, życia i świata. Wychowanie, nadzieja, wolność, doświadczenie Boga, rozwój człowieka, śmierć, melancholia, praca, rzeczywistość piękna i płaszczyzny obcowań międzyludzkich - świat człowieka nieodmiennie jest opisywany we wczesnych tekstach Tischnera przy pomocy instrumentarium filozofii wartości, a jawiące się problemy próbuje on stawiać i rozwiązywać aksjologicznie. Wartości w świecie jego namysłów filozoficznych były niewątpliwie kluczem do zrozumienia człowieka, jego natury i istoty oraz stanowily przestrzeń odpowiedzi na źródłowe pytanie etyki - jak żyć? W tym okresie Tischner wypracował swą teorię ja aksjologicznego jako najbardziej pierwotnego i źródłowego ja człowieka. Ja aksjologiczne stanowi irrealną wartość. Pisał:

Aksjologiczność owego Ja nie wynika z faktu realizacji (lub przynajmniej z decyzji realizacji) wartości pewnego typu i z jakiegoś ,ukwalifikowania” go przez już zrealizowane wartości, lecz polega na tym, że aksjologiczność jest jego immanentną rzeczywistością ${ }^{8}$.

Ja aksjologiczne, będąc wartością pozytywną w absolutnym znaczeniu tego słowa, bytuje w stronę wartości, wręcz można powiedzieć, że irrealne ja aksjologiczne urealnia się w ja społeczne dzięki realizacji wartości przedmiotowych ${ }^{9}$. Partyturą bytowania ludzkiego są właśnie wartości, a człowiekowi fundamentalnie chodzi w życiu o ich realizację, bardziej niż o własne bytowanie, a czasem nawet wbrew niemu ${ }^{10}$. W imię wartości człowiek potrafi rezygnować ze swego życia, oddać je w służbie wartościom, a więc potrafi zaprzeczyć jednej z najsilniejszych struktur instynktownych właściwych dla świata ożywionego.

Tischner zmierzył się zatem początkowo z krytyką wartości Heideggera i jego ontologią fundamentalną, wskazującą na zamknięcie troski Dasein w ramach własnego bycia. Wiele jego tekstów jest najczęściej nie wprost polemiką z Heideggerem, próbą wypracowania alternatywnej wizji bytu ludzkiego, w którym człowiek jest otwarty na drugiego, a partyturą jego życia sa

\footnotetext{
${ }^{6}$ J. Tischner, Myślenie wedtug wartości, Kraków 1982, s. 483.

${ }^{7}$ Por. tamże, s. 484.

${ }^{8}$ J. Tischner, Świat ludzkiej nadziei. Wybór szkiców filozoficznych 1966-1975, Kraków 1992,

${ }^{9}$ Por. tamże, s. 180

${ }^{10}$ Por. tamże, s. 200.
} s. 173. 
materialne wartości, istniejące obiektywnie w sposób uporządkowany i uhierarchizowany. Trzeba jednak zauważyć, że polemika wprost Tischnera z tezami Heideggera była dość śladowa i dotyczyła niewielu tekstów niemieckiego myśliciela. A przecież List o humanizmie, mówiący o bluźnierczym wobec bycia charakterze myślenia według wartości to tylko jeden $\mathrm{z}$ nich, zawierający zarzuty Heideggera wobec wartości jako kategorii filozoficznej. Wydaje się jednak, jak zostało już zauważone, że echo zarzutów Heideggera mocno utkwiło w świadomości Tischnera, który początkowo podjął próbę ich unieważnienia, polemiki z nimi, by jednak następnie coraz bardziej zbliżać się do stanowiska Heideggera w sprawie wartości, choć na innych niż on drogach myślowych, doświadczeniowych i operując innymi uzasadnieniami.

\section{MYŚLENIE WEDŁUG INNEGO I WEDłUG DOBRA}

Od końca lat siedemdziesiątych w myśleniu Tischnera wyraźnie następuje proces coraz większego docenienia, niewatpliwie pod wpływem filozofii dialogu, roli spotkania z drugim człowiekiem tak dla konstytuowania się tożsamości osobowej, jak i dla zaistnienia sytuacji moralnie powinnej, dla czucia świata wartości. Drugi człowiek otwiera perspektywę wartości, jest kluczem do ich zrozumienia i przeżycia aksjologicznego. Pisał Tischner: „W etyce wartością jest drugi człowiek, wartością jestem ja sam i wartościami są rozmaite płaszczyzny obcowań człowieka z człowiekiem"11. Wrażliwość personalistyczna fenomenologów, której przecież odmówić im nie można - wszak już w podtytule Der Formalismus Schelera czytamy: Neuer versuch der Grundlegung eines ethischen Personalismus - była jednak podporządkowana nadrzędnej kategorii doświadczeniowej, jaką w tych współrzędnych teoretycznych pełniła „wartość”. Człowiek to w perspektywie fenomenologicznej etyki wartości jedna $\mathrm{z}$ wartości moralnie doniosłych. Wartość różna w stosunku do przedmiotowych wartości, ale ustawiana $\mathrm{w}$ szeregu $\mathrm{z}$ innymi jakościami aksjologicznymi. Tischner ten porządek odwracał, podporządkowując w sensie epistemicznym i egzystencjalnym - niejako wszystkie wartości perspektywie drugiego człowieka, spotkania z nim. I właśnie taka perspektywa, wybijająca na plan pierwszy człowieka i spotkanie z nim, nie mieściła się w paradygmacie klasycznie rozumianej fenomenologicznej etyki wartości. Dla Schelera czy Hartmanna fundamentalny jest związek człowieka z wartościami, związek niezapośredniczony przez nic i przez nikogo, związek fundowa-

${ }^{11}$ J. Tischner, Etyka wartości i nadziei, w: D. v. Hildebrand, J.A. Kłoczowski, J. Paściak, J. Tischner, Wobec wartości, Poznań 1982, s. 52. 
ny na absolutnym apriorycznym poznaniu, uchwytującym wartość w jej istocie. Wartości domagają się realizacji (ściśle mówiąc realizacji swej materii) i swój apel kierują w stronę człowieka, wyposażonego w swoisty - mówiąc językiem Hartmanna - Wertorgan. Spotkanie z drugim człowiekiem nie jest w takich perspektywach żadną konstytuantą doświadczeń aksjomoralnych, nie jawi się jako konieczny warunek czucia wartości, ich doświadczania i odpowiadania na moment powinnościowy. Personalistyczno-dialogiczna perspektywa, którą dość radykalnie wprowadził Tischner, odbiega zatem od tego klasycznego dla fenomenologów schematu aksjologicznego. Zdania:

Kluczem do aksjologii jest spotkanie z drugim ${ }^{12}$ lub: pierwotnym źródłem doświadczenia etycznego nie jest przeżycie wartości jako takich, lecz odkrycie, że obok nas pojawił się drugi człowiek. Prawdziwym źródłem naszych etycznych doświadczeń jest człowiek [...]. To nie wartości, to nie normy, nie przykazania są ,pierwsze”, ale obecność drugiego człowieka ${ }^{13}$

w tym schemacie nie mieszczą się zdecydowanie. Drugi jawi się bowiem w świetle cytowanych wypowiedzi jako warunek konieczny dostępu do świata wartości, jako ten, kto tworzy sytuacje moralne i moralnie doniosłe, podczas gdy w klasycznej Wertethik, jak już powiedziano, człowiek to jedna z wyróżnionych, ale jednak wartości, konstytuujących szeroki świat aksjologiczny. U Tischnera staje się on swoistą metawartością, warunkiem odkrycia uniwersum aksjologicznego. Zaznacza się tu pewna wyraźna paralela ze stanowiskiem Emmanuela Levinasa, wyrażonym choćby w książce pt. Bóg, który nawiedza myśl, choć paralela ta ma swoje oczywiste granice. Pisał Levinas:

Relacja, w której Ja spotyka Ty, jest źródłowym miejscem i źródłowym warunkiem pojawienia się etyki. Fakt etyczny niczego nie zawdzięcza wartościom, to wartości wszystko mu zawdzięczają ${ }^{14}$.

Generalnie zresztą należy zauważyć, że spotkanie z myślą Levinasa powoduje dość zdecydowane zmiany w myśleniu Tischnera, wiele przewartościowań teoretycznych. Poszukując tego, co „pierwsze” odkrywa on porządek

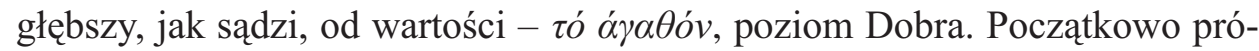
buje godzić porządek agatologiczny i porządek aksjologiczny - szuka modelu ich uporządkowania względem siebie, chcąc najwyraźniej usunąć jasno rysujące się napięcie w świecie jego myśli, spowodowane zderzaniem się dwóch paradygmatów filozoficznych: fenomenologii i filozofii dialogu, filo-

\footnotetext{
${ }^{12}$ J. Tischner, Myślenie..., s. 489.

${ }^{13}$ Tegoż, Etyka wartości..., s. 85.

${ }^{14}$ E. Levinas, O Bogu, który nawiedza myśl, tłum. M. Kowalska, Kraków 1994, s. 230.
} 
zofii wartości i dialogicznie rozumianej filozofii dobra. W płaszczyźnie agatologicznej człowiek doświadcza, że na poziomie faktycznym nie jest tak, jak być powinno, odsłania się pewna negatywność otaczającego go świata. Doświadczenie to mówi mu, że jest coś, czego nie powinno być, że w świat wsączyła się jakaś ułuda - rodzi to jaką́ formę buntu, który otwiera płaszczyznę aksjologiczna. W doświadczeniu aksjologicznym człowiek szuka konkretnego przeciwdziałania temu negatywnemu stanowi rzeczy, chce go zmienić, coś naprawić, czemuś zadośćuczynić. Pisał Tischner:

Doświadczenie agatologiczne jest przede wszystkim doświadczeniem odsłaniającym, zaś doświadczenie aksjologiczne doświadczeniem projektującym. Doświadczenie agatologiczne dotyczy bycia w świetle dobra, doświadczenie aksjologiczne dotyczy wydarzeń w świetle tego co wartościowe ${ }^{15}$.

Wydawało się zatem, że Tischner znalazł schemat takiego uporządkowania, a jednak czas pokazał, że on sam uznał go za niewystarczające i szukał bardziej radykalnych rozwiązań. W tym okresie Tischner zdecydowanie zaczął też dystansować się od problemów ontologii wartości, na plan pierwszy wysuwając zagadnienie nie sposobu istnienia wartości, lecz sposobu istnienia człowieka wobec wartości - czy człowiek realizuje czy sprzeniewierza się wartościom. Tischner zdawał się dostrzegać już na początku lat dziewięćdziesiątych, że dobro - w przeciwieństwie do wartości - dla legitymizacji swej ważności moralno-etycznej nie wymaga ontologii. Mówił:

Dobro nie wymaga ode mnie, abym akceptował jego istnienie. Dobro wymaga ode mnie, abym dał chleb głodnemu. Nawet jeżeli jest ono iluzją, to i tak nie wynika z tego, że nie powinienem dawać chleba głodnemu - a zatem istnienie czy nieistnienie takiego bytu jak Dobro nie wpływa w żaden sposób na moje zachowanie wobec drugiego człowieka ${ }^{16}$.

Problem relacji dobro - wartość okazał się bardziej skomplikowany niż początkowo wydawało się Tischnerowi. W każdym razie z biegiem czasu coraz większą rolę przywiązywał do kategorii dobra, rzadziej odwołując się do języka wartości. Tischnerowski język agatologiczny, który swój teoretyczny zwornik znalazł w kategorii dramatu, zdecydowanie zaczął wypierać język aksjologiczny. W Filozofii dramatu Tischner generalnie się nim już nie posługiwał. Dobro, prawda i piękno - klasyczna trójca metafizycznych kategorii zdaje się mu wystarczać, zresztą dostrzega w duchu klasycznym ich jedność. Drugi człowiek, spotkanie z nim wyparły „wartości”.

${ }^{15}$ J. Tischner, Myślenie...,, s. 490-491.

${ }^{16}$ Tenże, Uprawiam filozofię Dobra, w: Rozmowy o filozofii, red. A. Zieliński, M. Bagiński, J. Wojtysiak, Lublin 1996, s. 261. 
Być istotą dramatyczną - pisał - znaczy: przeżywać dany czas, mając wokół siebie innych ludzi i ziemię jako scenę pod stopami. Człowiek nie byłby egzystencją dramatyczna, gdyby nie te trzy czynniki: otwarcie na innego człowieka, otwarcie na scenę dramatu i przepływający czas ${ }^{17}$.

O wartościach, aksjologicznej partyturze bycia człowiekiem nie ma tu już mowy. Dramat jako kategoria antropologiczna i etyczna wyparł konieczność posługiwania się językiem wartości. Tischner zaczyna milczeć o wartościach, a w kolejnych tekstach zacznie o nich szczątkowo mówić, ale już w wyraźnie negatywnych kontekstach.

Rola drugiego jako Innego, spotkania z nim, odgrywa w myśleniu Tischnera nieodmiennie fundamentalną rolę: „Istnienie niesione przez innego jest agatologiczne"18. Tischner był w pełni świadomy napięcia, jakie w jego myśleniu wywoływały dwie kategorie: dobro i wartość, do czego jeszcze poniżej wrócimy. Natomiast zdaje się, że nie widział napięcia pomiędzy innymi kategoriami, którymi operował: „wartością” i „spotkaniem”, „wartością” i „Innym”. Przechodził nad nim do porządku dziennego, a zdaje się, że paradygmaty aksjologii fenomenologicznej i filozofii dialogu, z których pochodzą te dwa pojęcia, są sobie w najbardziej fundamentalnym sensie obce. Czy relacja etyczna jawi się w bezpośrednim odniesieniu człowieka do drugiego człowieka czy też w odniesieniu do przedmiotowo rozumianych wartości, nie jest wszak kwestią bez znaczenia. Jej rozstrzygnięcie wyznacza bardzo różne rozumienie moralności oraz eo ipso biegunowo różne profile etyki. W pierwszym przypadku mamy wyraźnie dialogiczny charakter moralności i etyki, w drugim monologiczny i egologiczny. To nie kwestia rozłożenia akcentów, lecz diametralnie różnych fizjonomii moralności i etyki. Zresztą wyparcie, jak wyżej sygnalizowano, ,wartości” poprzez dramat, którego nerwem jest otwarcie na innego człowieka, niejako naturalnie rozwiązało w myśleniu Tischnera o człowieku owo napięcie na korzyść modelu dialogicznego i spotkaniowego. Ferment personalistyczny w filozofii Tischnera okazał się zwycięski w stosunku do myślenia według wartości.

\section{MYŚLENIE PRZECIW WARTOŚCIOM?}

Z biegiem czasu w myśleniu Tischnera uwyraźniał się narastający zdecydowanie krytycyzm wobec ,wartości” jako kategorii filozoficznej. Jest to wprost widoczne w Sporze o istnienie człowieka oraz w artykule lub notat-

${ }^{17}$ Tenże, Filozofia dramatu. Wprowadzenie, Paryż 1990, s. 11.

${ }^{18}$ Tamże, s. 66. 
kach do wykładów z połowy lat dziewięćdziesiątych, a nie wprost w wielu późnych tekstach, w których Tischner całkowicie rezygnuje z retoryki aksjologicznej na rzecz zupełnie innego języka, którego zaczyna wyraźnie poszukiwać i wypracowywać jego zręby. Posługiwał się nim nawet w doraźnej publicystyce z lat dziewięćdziesiątych. Źródła do rekonstrukcji tego późnego stanowiska Tischnera wobec wartości są bardzo szczupłe, stąd - jak się wydaje - częste przechodzenie nad nimi komentatorów do porządku dziennego i bezkrytyczne operowanie hasłem „myślenia według wartości” jako cechy charakterystycznej całej filozofii Tischnera. Trzeba jednak, jak się wydaje, uwzględnić te szczupłe źródła do zmiany stanowiska Tischnera wobec myślenia $\mathrm{w}$ ramach filozofii wartości.

W Sporze o istnienie człowieka pisał Tischner:

Odkryciu wymiaru uczestnictwa w dobru zagraża uprzedmiotowienie w wartości. Od dłuższego już czasu utrzymuje się w filozofii dążenie do zastąpienia pojęcia dobra pojęciem wartości. Usiłuje się w ten sposób przybliżyć dobro doświadczeniu fenomenologicznemu. Czy jednak cel ten został osiagnnięty? W istocie tym, co się osiaga, jest estetyzacja dobra: dobro sprowadzone do porządku wartości staje się wartością estetyczną ${ }^{19}$.

Wartości zatem zagrażają czymś bardzo niebezpiecznym, mianowicie zamianą uczestnictwa w dobru na uprzedmiotowienie w przedmiotach-wartościach, przejściem $\mathrm{z}$ poziomu dialogicznej obecności na poziom intencjonalnego uchwytywania, doświadczenia przedmiotowego. W cytowanym fragmencie Tischner stwierdza fiasko fenomenologicznego celu, jakim było przybliżenie człowiekowi dobra na drodze wartości. Cel nie tylko nie został osiagnięty, ale wygenerował bardzo niebezpieczny trop utożsamiania dobra $\mathrm{z}$ kategoriami estetycznymi. Zauważmy, że estetyzacja dobra i egzystencji człowieka to jedna z podstawowych idei współczesnej etyki i antropologii postmodernistycznej. Czyżby zatem aksjologiczne ugruntowanie etyki pociagało za sobą postmodernistyczny wariant likwidacji etyki w jej klasycznym rozumieniu? Czy estetyzacja życia $\mathrm{z}$ wszystkimi konsekwencjami teoretycznymi, a przede wszystkim praktycznymi leży na przedłużeniu myślenia według wartości? Tych pytań Tischner wprost nie stawia. Odnośnie do estetyzacji dobra pisze jeszcze:

Wszystko zamyka się w stwierdzeniu: to, co piękne, jest dobre, i to, co dobre jest piękne. Absolut dobra staje się absolutem piękna. Absolut ten daje się następnie „,uprzedmiotowić” w dziele sztuki, a jeszcze bardziej w teorii ,,przedmiotowego dzieła sztuki"'20.

\footnotetext{
${ }^{19}$ Tenże, Spór o istnienie czlowieka, Kraków 1998, s. 177.
}

${ }^{20}$ Tamże. 
Podobieństwo tego opisu z rozumieniem życia jako dzieła sztuki Michela Foucault jest wyraźne i wręcz narzucające się. Tyle, że Tischner postrzega proces uprzedmiotowienia dobra $\mathrm{w}$ dziele sztuki jako wy-naturzenie dobra, a dla postmodernizmu jest to właśnie jego uwolnienie spod dyktatu autorytetów i tradycyjnej moralności, jest procesem wartościowanym jak najbardziej pozytywnie.

W późnym tekście, być może notatkach do wykładu lub pełniejszego artykułu, pt. Tajemnica kilku pojęć teatralnych Tischner sformułował szereg innych, bardzo istotnych wątpliwości przeciw myśleniu według wartości. Czytamy tam m.in.:

Słowo „wartość” robi od niejakiego czasu dość niezwykłą karierę. Wszyscy mówią o ,wartościach”, a są nawet tacy, którzy sięgają po przemoc, by bronić nas przed agresją świata bez wartości ${ }^{21}$.

Zauważmy: kariera „wartości” jako pojęcia filozoficznego posiada krótką historię i jest „dość niezwykła”. Rzeczywiście do wieku XIX myślenie filozoficzne czy etyczne doskonale radziło sobie bez „wartości”, odwołując się do dobra, cnoty etc., a dopiero jej dziewiętnastowieczny transfer z myślenia ekonomicznego do filozofii okazał się niezwykle rozwojowy. Dobro w myśli Platona to najwyższa idea, oświetlająca człowieka i ujawniająca przed nim prawdę i piękno, świecąca, można rzec, z góry. Pisał Tischner: „Wartości” pojawity się dopiero wtedy, gdy zniknęty ,,dobra”, a miejsce ,światta z góry” zajęty ,, światta z boku"'22. Zamiana wymiarów wertykalnych na horyzontalne byłaby więc osiowym wskaźnikiem przejścia od etyki typu agatonicznego do etyki aksjologicznej. Tischner w tym kontekście przywołuje nauki przyrodnicze, które, jego zdaniem, zredukowały wszystkie jakości świata do jednego wymiaru, elementu - do przestrzeni. „Muzyka stała się określoną długością fali, barwa inną długością fali, nawet smak miodu na języku stał się rodzajem drgań, pobudzających zakończenia komórek nerwowych"23. Protest przeciw temu redukcjonizmowi przyszedł ze strony zmysłowości (szczególnie było to widoczne w romantyzmie), która nie chciała dać się zamknąć w kwantytatywnie rozumianej przestrzenności, podlegającej mierzeniu, porównywaniu, obliczaniu. Zdaniem Tischnera, zmysły w ten sposób brały odwet na rozumie. „Wartość” byłaby więc związana z bezpośredniością, wrażliwością na to, co bezpośrednio, zmysłowo dane: śpiew ptaka, błysk światłą w oczach, płacz dziewczyny. Wartości pociągają i odpychają, zachwycają i budzą wstręt.

\footnotetext{
${ }^{21}$ Tenże, Tajemnica kilku pojęć teatralnych, „Tygodnik Powszechny” 19, 11 maja 2008, s. 24.

${ }^{22}$ Tamże.

${ }^{23}$ Por. tamże, s. 25.
} 
Zmysły, które to odkrywają są genialne - „genialność zmysłów” to określenie Sørena Kierkegaarda. I teraz ważne słowa Tischnera:

Weźmy [...] pod uwagę kogoś takiego jak Matka Teresa. Czy jej dzieło ma coś wspólnego z „genialnością zmysłów”? Rzekłbym raczej: walcząc z nieszczęściami tego świata, Matka Teresa „czyni dobrze”. Wynika z tego: dobro jest jakby inne niż wartości. Może mniej bezpośrednie? Może mniej krzykliwe? Może skromniejsze? Jego „reguły” są inne24.

Tak więc logika dobra i logika wartości nie są tą samą logiką. Można zatem zaryzykować tezę, że aksjologiczne ugruntowanie etyki i stosowanie w niej języka wartości heterogenizuje jej istotę, wprowadza obce jej „reguły”, pochodzące z przestrzeni zmysłowości. Stąd zapewne, zdaniem Tischnera, bierze się estetyzacja moralności w etyce wartości. Odnośnie do powszechności języka wartości Tischner zauważa z wyraźnym sarkazmem:

Nawet chrześcijanie bronią dziś „wartości chrześcijańskich”. Nie widać jednak, by coś podobnego czynił św. Paweł. Czyżby „wartości chrześcijańskie” były mu zupełnie obce? $?^{25}$

Owszem, w swej ostatniej książce pt. Drogi i bezdroża miłosierdzia Tischner używa miejscami języka wartości, pisząc o Nietzschem i siostrze Faustynie, o resentymencie i tytułowym miłosierdziu. Czytamy, dla przykładu: „Każde Ja nosi ze sobą partyturę wartości, wedle której gra swoje życie"26. Wydaje się to jednak uwarunkowane sytuacyjnie omawianym problemem narzucającym wręcz frazeologię aksjologiczną.

Późny Tischner najwyraźniej zatem zdecydowanie przechodził z pozycji myślenia według wartości na pozycję myślenia przeciw wartościom. Niewątpliwie swej nowej koncepcji nie zdążył opracować, zarysowując ledwie jej kontury. Jego silne zaangażowanie w sprawy społeczne oraz przedwczesna śmierć uniemożliwiły wypracowanie równie zwartego jak wczesny paradygmat myślenia w żywiole wartości paradygmatu myślenia agatycznego, przeciwstawianego myśleniu według wartości. Wszak zarzuty przeciw temu myśleniu, wyżej zasygnalizowane, były zdecydowane i wyostrzały się w czasie. Trudno przejść nad nimi do porządku dziennego, widząc w Tischnerze przedstawiciela fenomenologicznego myślenia według wartości. Wydaje się, że antyaksjologiczny duch Heideggera zaczął jednak w Tischnerze zwyciężać. Trop myślowy o agatologicznym wymiarze obecnym w istnieniu drugiego jest

\footnotetext{
24 Tamże.

${ }_{25}$ Tamże.

26 Tenże, Drogi i bezdroża miłosierdzia, Kraków 1999, s. 59.
} 
wzbogaconym o wątek dialogiczny tropem Heideggera mówiącym o byciu jako przestrzeni wy-darzania się prawdy, także prawdy dobra.

Analizując odchodzenie Tischnera od programu myślenia według wartości wyraźnie dostrzega się korelację czasową tego oddalania z dystansowaniem się wobec fenomenologii jako takiej, wobec programu Husserla, który zapoczątkował wielki ruch filozoficzny dwudziestego wieku ${ }^{27}$. Horyzont doświadczeń i namysłów filozoficznych Tischnera kazał mu oddalić się od programu klasycznej fenomenologii. Tischner wykazał się zatem odwagą godną filozofa i filozoficzną odpowiedzialnością za prawdę, potrafiąc porzucać modele i metody uznawane wcześniej za optymalne i słuszne. W 1974 roku w redakcji „Znaku” mówił:

Funkcją filozofii jest radykalne zapytywanie. Radykalne, nie znające kompromisów pytanie samo otwiera obszar możliwej odpowiedzialności filozofa. Filozof staje się autorem nie tylko odpowiedzi, lecz jest również świadomym sprawcą pytań, na które odpowiada. [...]. Muszę tu przyznać, że zawsze zdumiewała mnie u filozofów odwaga, z jaką podejmowali swe radykalne pytania ${ }^{28}$.

W tym właśnie duchu Tischner wykazał się odwagą rewizji swych wcześniejszych tez, rezygnacją z rudymentów filozofowania przyjmowanych wcześniej, odpowiedzialnością za filozoficzną ,rzecz myślenia”, bo jak wiadomo od Arystotelesa, cytując w wersji zlatynizowanej, amicus Plato, magis tamen amica veritas.

Powyższy tekst to tylko szkic, przyczynek do problemu - dokładne analizy wszystkich tekstów Tischnera pozwoliłyby wydobyć wiele innych interesujących elementów jego przygody z myśleniem według wartości, kreślonych biegunami afirmacji i negacji. Każdy z wyróżnionych powyżej etapów ewolucji myśli Tischnera wymaga zniuansowania, ukazania nieliniowości tego procesu ewolucji. Osobną kwestią jest zagadnienie dyskusji nad blaskami i cieniami aksjologicznego ugruntowania moralności i etyki. Nie podjęliśmy tu problemu oceny samych projektów myślenia według wartości i myślenia przeciw wartościom, interesował nas wyłącznie bardzo doniosły i symptomatyczny, jak można sądzić, wątek przygody Józefa Tischnera z filozofią wartości.

\footnotetext{
${ }^{27}$ Por. K. Stachewicz, Człowiek i jego ethos, Poznań 2011, s. 71-87.

${ }^{28}$ O odpowiedzialności filozofa, ,Znak” 240, 1974, s. 722.
} 


\section{SUMMARY}

The article reconstructs a certain element of the evolution in Józef Tischner's thinking. Initially representing orthodox phenomenology, Tischner situated his philosophy in exiological paradigm seeing in values the most fundamental reality and the main object of philosophical research. Later, thanks to agathological dimensions he put aside the language of values and sometimes doubted adequacy of values as philosophical category. Tischner revealed courage when he was able to radically revise his former views according to the principle: amicus Plato, magis tamen amica veritas.

\section{Key words:}

Tischner, Scheler, Heidegger, Levinas, values, the good, axiology, agatology 